Assiut University web-site: $\underline{w w w . a u n} . e d u . e g$

\title{
MYCOLOGICAL EVALUATION OF MILK AND SOME MILK PRODUCTS IN BENI-SUEF CITY
}

\author{
SAADIA H. EL-SHINAWY; ADEL M. EL-KHOLY; ARAFA M.S. MESHREF and \\ SAMMER W. SHARKAWY
}

Faculty of Veterinary Medicine, Beni Suef University, Beni-Suef, Egypt

Received: 31 December 2017; $\quad$ Accepted: 30 January 2018

\begin{abstract}
A total of 125 random samples from raw milk, locally manufactured kareish cheese, hard cheese (Rass cheese), plain yoghurt and flavored yoghurt (25 of each) collected from dairy shops and super markets in Beni Suef city were subjected to mycological examination. The yeasts were detected in milk, Rass cheese and locally manufactured kareish samples with a mean value of $6.22 \times 10^{2} \pm 3.62 \times 10^{2}, 14 \pm 7.21$ and $3.23 \times 10^{6} \pm 2.017 \times 10^{6}$ respectively, while plain yoghurt and flavored yoghurt were free from any yeasts $(<10)$. The most predominant isolated spp. were Candida pseudotropicalis, Rhodotorula species, Candida species, Torulopsis (candida) glabrata and Cryptococcus neoformans. The mean value of molds was $2.23 \times 10^{2} \pm 9.3 \times 10^{1}, 4.8 \pm 1.54$, $1.068 \times 10^{6} \pm 7.20 \times 10^{5}$, and $2.4 \pm 0.871$ in the examined milk, Rass, locally manufactured kareish cheese and flavored yoghurt samples respectively, while molds couldn t be detected in the examined plain yoghurt samples. The most predominant isolated spp. Were Mucorspp, Asperigellus flavus, Asperigellus niger, Asperigellus fumigatus, Absidia spp., Penicillium spp., Geotrachum candidum, Cladosporium spp., Phoma spp. and Fusarium spp. All the examined Rass cheese samples were free from aflatoxin M1 calibrated by fluorometer. The economic and public health significance of the fungi and mycotoxins as well as the sanitary precautions were mentioned.
\end{abstract}

Key words: Yeast, mold, mycotoxins, milk, dairy products.

\section{INTRODUCTION}

Milk has been used by human since the beginning of the life as the mostpopular and nutritious safe human food, this value put the food hygienists in a real challenge, to provide safe milk to consumer and at the same time keep its nutritional value high as much as possible. In some countries including Egypt, most milk is manufactured into more stable dairy products of worldwide commerce, such as cheese andyoghurt.

The manufactured dairy products from milk have the same properties of original milk moreover; several stages of processing may be unfavorable and add more points of hazard and weakness allowing entrance of molds and unfortunately, these products support molds growth and toxins production due to its contents of protein, low $\mathrm{pH}$ and storage under unfavorable conditions Gqaleni et al. (1997); Pardo et al. (2004).

Corresponding author: Dr. SAMMER W. SHARKAWY E-mail address: ashrykhaled@gmail.com

Present address: Faculty of Veterinary Medicine, Beni Suef University, Beni-Suef, Egypt
Yeasts and molds can grow in milk and its products particulary at suitable conditions of temperature and moisture Barrois et al. (1997). Contamination of these products may occur from the raw material or during the manufacturing, storage and distribution Kure et al. (2004). Such microorganisms influence the biochemical characters and flavor of such products as well as their appearance rendering them commercially undesirable and often resulting in decreasing the grading of the dairy products Muir and Banks (2000).

Mycotoxins produced by certain molds as a toxic substances can be found in dairy products from two origins: indirect contamination, which results when dairy cows ingest feed that contains mycotoxins which pass into the milk such as aflatoxin M1 and direct contamination, which occurs due to the intentional or accidental growth of molds on the surface of the dairy products and secrete aflatoxins B1, B2, G1 and G2 Sengun et al. (2008) therefore, feeding on a low quality ration contaminated with molds more than $10 \mathrm{cfu} / \mathrm{g}$ and kept under humid conditions cause intoxication to both animals and human whom consumed this animal products.

The present work was performed to investigate the presence of molds and yeasts in milk and some milk 
products in Beni- Suef city, identification of isolated strains and detection of mycotoxins in Rass cheese samples.

\section{MATERIALS AND METHODS}

Collection of the samples:

A total of 125 random samples from raw milk, locally manufactured kareish cheese, hard cheese (Rass cheese), plain yoghurt and flavored yoghurt (25 of each) were collected from dairy shops and super markets in Beni-Suef city for mycological and mycotoxicological examination.

Preparation of the samples (A.P.H.A.1992):

Raw milk samples were subjected to storch's test lampert (1975) to exclude all samples proved to be heat treated.

Rass and kareish cheese samples were thoroughly mashed before being emulsified in the diluted solution.

Whole yoghurt samples were perfectly mixed before examination.

Eleven $\mathrm{ml}$ or $\mathrm{g}$ of each prepared fluid milk and yoghurt samples were added to $99 \mathrm{ml}$ of sterile saline to make adilution of $1 / 10$, from which serial dilutions were prepared. In Rass cheese and kareish cheese samples, Eleven grams of prepared samples were aseptically transferred to a sterile blender jar and 99 $\mathrm{ml}$ of warmed $\left(40^{\circ} \mathrm{C}\right)$ sterile $2 \%$ sodium citrate solution were added and the contents were blended till completely emulsified to make a dilution of $1 / 10$ from which decimal dilution were prepared.

Mycological examination (Bailey and Scott, 1978): From the already prepared serial dilution, one ml was transferred into duplicate petri-dishes and thoroughly mixed with $15 \mathrm{ml}$ of sabaroud dextrose agar containing $50 \mathrm{ppm}$ chloramphenicol Hup and Staddhouders (1972). The inoculated plates were incubated at $25^{\circ} \mathrm{C}$ for 7 days. The first examination of the plates was done after 3 days to determine the degree of fungi growth. The yeasts and molds count $/ \mathrm{ml}$ or $\mathrm{g}$ was calculated and recorded.

Representative colonies were isolated on the sabaroud dextrose agar slopes which incubated at $25^{\circ} \mathrm{C}$ for 5 days for further identification.

Isolated molds were identified according to Ramirez (1982); Samson (1979), while yeasts colonies were identified according to lodder (1970).

Aflatoxin M1 in Rass cheese samples was detected by using fluorometer Scott and Trucksess, (1997).

\section{RESULTS}

Table 1: Statistical analytical results of yeasts and molds Counts in the examined raw milk samples.

\begin{tabular}{lccccccc}
\hline Isolates & $\begin{array}{c}\text { No of the examined } \\
\text { samples }\end{array}$ & \multicolumn{2}{c}{$\begin{array}{c}\text { No of positive } \\
\text { samples }\end{array}$} & Min/ml & Max/ml & Mean/ml & \pm SEM \\
\cline { 3 - 6 } & & No & $\%$ & & & \\
\hline Yeasts & 25 & 17 & 68 & $<10$ & $9 \times 10^{3}$ & $6.22 \times 10^{2}$ & $3.62 \times 10^{2}$ \\
\hline Molds & 25 & 16 & 64 & $<10$ & $1.6 \times 10^{3}$ & $2.23 \times 10^{2}$ & $9.3 \times 10^{1}$ \\
\hline
\end{tabular}

Table 2: Statistical analytical results of yeasts and molds counts in the examined Rass cheese samples.

\begin{tabular}{lccccccc}
\hline Isolates & $\begin{array}{c}\text { No of the examined } \\
\text { samples }\end{array}$ & $\begin{array}{c}\text { No of positive } \\
\text { samples }\end{array}$ & & Min/g & Max/g & Mean/g & \pm SEM \\
\cline { 3 - 7 } & 25 & No & $\%$ & & & & \\
\hline Yeasts & 25 & 6 & 24 & $<10$ & $1.5 \times 10^{2}$ & 14 & 7.21 \\
\hline Molds & 8 & 32 & $<10$ & $0.2 \times 10^{2}$ & 4.8 & 1.54 \\
\hline
\end{tabular}


Table 3: Statistical analytical results of yeasts and molds counts in the examined Kareish cheese samples.

\begin{tabular}{cccccccc}
\hline Isolates & $\begin{array}{c}\text { No of the examined } \\
\text { samples }\end{array}$ & $\begin{array}{c}\text { No of positive } \\
\text { samples }\end{array}$ & Min/g & Max/g & Mean/g & \pm SEM \\
\cline { 3 - 7 } & & No & $\%$ & & & \\
\hline Yeasts & 25 & 16 & $64 \%$ & $<10$ & $0.5 \times 10^{8}$ & $3.23 \times 10^{6}$ & $2^{2.017 \times 10^{6}}$ \\
\hline Molds & 25 & 15 & $60 \%$ & $<10$ & $1.8 \times 10^{7}$ & $1.068 \times 10^{6}$ & $7.20 \times 10^{5}$ \\
\hline
\end{tabular}

Table 4: Statistical analytical results of yeasts and molds counts in the examined large scale yoghurt samples.

\begin{tabular}{|c|c|c|c|c|c|c|c|c|}
\hline \multirow{2}{*}{$\begin{array}{c}\text { The } \\
\text { examined } \\
\text { samples }\end{array}$} & \multirow[t]{2}{*}{ Isolates } & \multirow{2}{*}{$\begin{array}{l}\text { No of the } \\
\text { examined } \\
\text { samples }\end{array}$} & \multicolumn{2}{|c|}{$\begin{array}{l}\text { No of positive } \\
\text { samples }\end{array}$} & \multirow[t]{2}{*}{ Min/g } & \multirow[t]{2}{*}{$\operatorname{Max} / g$} & \multirow[t]{2}{*}{ Mean/g } & \multirow[t]{2}{*}{$\pm \mathrm{SEM}$} \\
\hline & & & No & $\%$ & & & & \\
\hline \multirow{2}{*}{$\begin{array}{c}\text { Flavoured } \\
\text { yoghurt }\end{array}$} & Yeasts & 25 & $\mathbf{0}$ & 0 & $<10$ & $<10$ & $<10$ & $<10$ \\
\hline & Molds & 25 & 6 & 24 & $<10$ & $0.1 \times 10^{2}$ & 2.4 & 0.87 \\
\hline \multirow[t]{2}{*}{ Plain yoghurt } & Yeasts & 25 & $\mathbf{0}$ & $\mathbf{0}$ & $<10$ & $<10$ & $<10$ & $<10$ \\
\hline & Molds & 25 & $\mathbf{0}$ & $\mathbf{0}$ & $<10$ & $<10$ & $<10$ & $<10$ \\
\hline
\end{tabular}

Table 5: Incidenceof the identified yeasts isolates.

\begin{tabular}{|c|c|c|c|c|c|c|c|c|c|c|c|}
\hline \multirow[t]{2}{*}{ Yeast species } & \multirow{2}{*}{$\begin{array}{c}\text { No of the } \\
\text { examined } \\
\text { samples }\end{array}$} & \multicolumn{2}{|c|}{ Milk } & \multicolumn{2}{|c|}{$\begin{array}{l}\text { Kareish } \\
\text { cheese }\end{array}$} & \multicolumn{2}{|c|}{$\begin{array}{l}\text { Romano } \\
\text { cheese }\end{array}$} & \multicolumn{2}{|c|}{$\begin{array}{c}\text { Plan } \\
\text { yoghurt }\end{array}$} & \multicolumn{2}{|c|}{$\begin{array}{c}\text { Flavoured } \\
\text { yoghurt }\end{array}$} \\
\hline & & $+v e$ & $\%$ & $+v e$ & $\%$ & $+v e$ & $\%$ & $+v e$ & $\%$ & $+v e$ & $\%$ \\
\hline $\begin{array}{c}\text { Candida } \\
\text { pseudotropicalis }\end{array}$ & 25 & 6 & $24 \%$ & - & - & 1 & $4 \%$ & - & - & - & - \\
\hline $\begin{array}{l}\text { Rhodotorula } \\
\text { species }\end{array}$ & 25 & 1 & $4 \%$ & - & - & - & - & - & - & - & - \\
\hline Candida species & 25 & 9 & $36 \%$ & 12 & $48 \%$ & 3 & $12 \%$ & - & - & - & - \\
\hline $\begin{array}{c}\text { Torulopsis } \\
\text { (candida) glabrata }\end{array}$ & 25 & 1 & $4 \%$ & 3 & $12 \%$ & 2 & $8 \%$ & - & - & - & - \\
\hline $\begin{array}{l}\text { Cryptococcus } \\
\text { neoformans }\end{array}$ & 25 & - & - & 2 & $\mathbf{8 \%}$ & - & - & - & - & - & - \\
\hline
\end{tabular}


Table 6: Incidenceof the identified molds isolates.

\begin{tabular}{|c|c|c|c|c|c|c|c|c|c|c|c|}
\hline \multirow[t]{2}{*}{ Molds species } & \multirow{2}{*}{$\begin{array}{l}\text { No of the } \\
\text { examined } \\
\text { samples }\end{array}$} & \multicolumn{2}{|c|}{ Milk } & \multicolumn{2}{|c|}{$\begin{array}{l}\text { Kareish } \\
\text { cheese }\end{array}$} & \multicolumn{2}{|c|}{$\begin{array}{l}\text { Romano } \\
\text { cheese }\end{array}$} & \multicolumn{2}{|c|}{$\begin{array}{c}\text { Plan } \\
\text { yoghurt }\end{array}$} & \multicolumn{2}{|c|}{$\begin{array}{c}\text { Flavoured } \\
\text { yoghurt }\end{array}$} \\
\hline & & +ve & $\%$ & $+\mathrm{ve}$ & $\%$ & + ve & $\%$ & + ve & $\%$ & $+\mathrm{ve}$ & $\%$ \\
\hline Mucor spp. & 25 & 2 & $8 \%$ & - & - & 2 & $8 \%$ & - & - & 2 & $8 \%$ \\
\hline $\begin{array}{l}\text { Asperigellus } \\
\text { flavus }\end{array}$ & 25 & 2 & $8 \%$ & 6 & $24 \%$ & 1 & $4 \%$ & - & - & 2 & $8 \%$ \\
\hline Asperigellus niger & 25 & 3 & $12 \%$ & 7 & $28 \%$ & 2 & $8 \%$ & - & - & - & \\
\hline $\begin{array}{l}\text { Asperigellus } \\
\text { fumigatus }\end{array}$ & 25 & $\mathbf{1}$ & $4 \%$ & - & - & 2 & $8 \%$ & - & - & - & \\
\hline Absidia spp. & 25 & - & - & 2 & $8 \%$ & 1 & $4 \%$ & - & - & - & \\
\hline Penicillium spp. & 25 & - & - & - & - & - & & - & - & 1 & $4 \%$ \\
\hline $\begin{array}{l}\text { Geotrachum } \\
\text { candidum }\end{array}$ & 25 & 6 & $24 \%$ & - & - & - & & - & - & 1 & $4 \%$ \\
\hline $\begin{array}{c}\text { Cladosporium } \\
\text { spp. }\end{array}$ & 25 & 1 & $4 \%$ & - & - & - & & - & - & - & \\
\hline Phoma spp. & 25 & 1 & $4 \%$ & - & - & - & & - & - & - & \\
\hline Fusarium spp. & 25 & $\mathbf{1}$ & $4 \%$ & - & - & - & & - & - & - & \\
\hline
\end{tabular}

\section{DISCUSSION}

The Results given in Table 1 revealed that the examined milk samples were contaminated with yeasts and molds at percentages of $68 \%$ and $64 \%$, respectively with a mean value of $6.22 \times 10^{2} \pm$ $3.62 \times 10^{2} \mathrm{cfu} / \mathrm{g}$ and $2.23 \times 10^{2} \pm 9.3 \times 10^{1} \mathrm{cfu} / \mathrm{g}$, respectively. Similar results were reported by Ghazal (2001), while higher molds and yeasts counts were observed in samples examined by El-Diasty and ElKaseh (2009); Pešić-Mikulec et al. (2005); Lavoie et al. (2012). The obtained results indicated poor hygiene during handling which might lead to technological problems during processing.

The data summarized in Table 2 revealed that yeasts and molds were isolated from Rass cheese samples at a percentage of $24 \%$ and $32 \%$ respectively with a mean value of $14 \pm 7.21 \mathrm{cfu} / \mathrm{g}$ and $4.8 \pm 1.54 \mathrm{cfu} / \mathrm{g}$ respectively. Higher counts with lower incidence were reported by Al- Hawary et al. (2002); Amer (2002); El-Asuoty (2011).

The obtained results in Table 3 showed that the count of total yeasts and molds in the examined kareish cheese samples were detected at a percentage of $64 \%$ and $60 \%$ respectively with a mean value of $3.23 \times 10^{6} \pm$ $2.017 \times 10^{6}$ and $1.068 \times 10^{6} \pm 7.20 \times 10^{5} \mathrm{cfu} / \mathrm{g}$. Similar counts were detected by Moawad et al. (2002), while higher counts with lower incidence were reported by Khair-Allah (2000); Hassan (2003), lower counts and incidence were recorded by El-shrief (2000); ElKomy (2002).

The results given in Table 4 proved that the total molds existed in the examined flavored yoghurt samples at a percentage of $24 \%$ with a mean value of $2.4 \pm 0.87178 \mathrm{cfu} / \mathrm{g}$. Higher results for the count were recorded by Moustafa (2004); Hafez (2010); Hassan (2003).

On the other hand the yeasts failed to be detected in the flavoured yoghurt samples, but both yeasts and molds couldn't be detected in the plain yoghurt samples. The achieved results allow concluding that most of the examined samples proved to be not contaminated with molds and yeasts, which indicate good hygienic measures during production, handling, storage and distribution. The presence of molds in large scale products may be attributed to post pasteurization contamination and/or unsanitary measures during handling and distribution.

Species of Candida pseudotropicalis, Rhodotorula species, Candida species, Torulopsis (candida) glabrata and Cryptococcus neoformans could be isolated from the different samples at varying percentage in Table (5). Several authors obtained the same results as El-Diasty and El- Kaseh (2009); Sarais et al. (1996).

Species of Mucor spp., Asperigellus flavus, Asperigellus niger, Asperigellus fumigatus, Absidia 
spp., Penicillium spp., Geotrachum candidum, Cladosporium spp., Phoma spp. and fusarium spp. could be isolated from the perivous samples as in Table 6 Several authors obtained the same results ElDiasty and El- Kaseh (2009); Karthikeyan and Pandiyan (2013) and Gulbe and Valdovska (2014).

On the other hand aflatoxin $\mathrm{M} 1$ residue couldn $\mathrm{t}$ be detected in the examined Rass cheese samples. The result is similar to Robinson and tamime (1991); Martins et al. (1995); Škrinjar et al. (2011).

Mold and yeast contamination not only causes deterioration of food but also can adversely affect the health of humans. Moreover, fungi influence the biochemical characters and flavor of the product and its appearance is commercially undesirable and often result in down grading of the product.

It is concluded that strict hygienic measures should be applied during production, processing and distribution of milk and its products to avoid contamination. Periodical inspection must be done by specialists on the dairy farms to minimize milk contamination with different types of yeasts and molds. The milk obtained from dairy animals fed on feedstuffs contaminated with aflatoxin B1 must be rejected. Efficient cleaning and sanitization of farm dairy utensils must be done to improve the quality of raw milk and consequently the related dairy products. Also, monitoring programs should be more extensive with a particular attention in monitoring aflatoxin in milk and milk products. The milk and milk products should be kept under refrigeration and the practice of display at room temperature should be discouraged.

\section{REFERENCES}

A.P.H.A. "American Public Health Association" (1992): Standard methods for the examination of dairy produts $16^{\text {th }}$ Ed., American Public Health Association. Washington.

Al-Hawary, I.I.; Sobeih, A.M.K. and Aman, I. (2002): Microbiological evaluation of cheeses and milk powder in Kafr El-Sheikh and El-Gharbia governorates. Minufyia Vet. Med. J. 2 (1): 265-276.

Amer, A.A.A. (2002): Safety and quality of butter and cheese through mycological criteria Thesis, Ph.D., Fac. Vet. Med., Alexandria Univ., Egypt.

Bailey, W.R. and Scott, E.G. (1978): Diagnostic microbiology. A textbook for the isolation and identification of pathogenic microorganisms. The C.V. Mosby by company, Saint Louis, Toronto, London.

Barrios, M.J.; Medina, L.M.; Cordoba, M.G. and Jordano, R. (1997): Aflatoxin producing strains of aspergillus flavus isolated from cheese. J. food Prot. 60: 192-194.
El-Asuoty, M.S.M.I. (2011): Mycological evaluation of some dairy products with special references to mycotoxins production, Thesis, Ph.D., Fac. Vet. Med., Alexandria Univ., Egypt.

El-Diasty, E.M. and El-Kaseh, R.M. (2009): Microbiological monitoring of raw milk and yoghurt samples collected from El-Beida city. Arab J. Biotech, 12, (1): 57-64.

El-Komy, K. (2002): Pollution of some street vended dairy products by moulds of public health hazard. Thesis, M.V.SC., Fac. Vet. Med., Alexandria Univ., Egypt.

El-Shrief, L.M.T. (2000): Incidence of mycoflora and some mycotoxins in locally manufactured cheese. Thesis, M.V.Sc. Fac. Vet. Med., Assiut Univ., Egypt.

Ghazal, G.H. (2001): Mycological studies of raw milk and cheese. Ph.D. Thesis, Fac. of Vet. Med. Zagazig Univ., Egypt.

Gqaleni, N.; Smith, J.E.; Lacey, J. and Gettinby, G. (1997): Effects of temperature, water activity and incubation time on production of aflatoxins and cyclopiazonic acid by an isolate of Aspergillus flavusi surface agar culture. J. Appl. Environ. Microbiol., 63: 1048-1053.

Gulbe, G. and Valdovska, A. (2014): Diversity of microscopic fungi in the raw milk from Latvian organic farms, Proc. Latv. Uni. Agr., 2014, 31 (326) 46-53.

Hafez, D.A.A. (2010): Sanitary condition of some processed milk products sold in Beni-Suef city. Thesis, M.V.SC. Fac. Vet. Med., Benisuefuniv., Egypt.

Hassan, G.M. (2003): Quality assessment of some dairy products at consumer level. Thesis, Ph.D., Fac. Vet. Med., Cairo Univ. Beni-suef branch, Egypt.

Hup, H. and Stadhounders, R. (1972): In "Food and Beverage Mycology" $2^{\text {nd }}$ ed. (Lorry R. Bevchat, 1978). AVI publishing company INC, wesport, Connecticut pp:484.

Karthikeyan, N. and Pandiyan, C. (2013): Microbial quality of Khoa and Khoa based milk sweets from different sources. Int Food Res. J. 20(3): 1443-1447.

Khair-Allah, H.M. (2000): Safety and quality of some dairy products through microbial criteria. Thesis M.V.SC., Fac. Vet. Med. Alexandria Univ.

Kure, C.F.; Skaar, I. and Brendehaug, J. (2004): Mold contamination in production of semi hard cheese Int. J. food Microbiology. 15:93:41-49.

Lampert, L.M. (1975): Modern dairy products. $3^{\text {rd }} \mathrm{ED}$ chemical publishing company. Inc. New York, U.S.A.

Lavoie, K.; Touchette, M.; St-Gelais, D. and Labrie, $S$. (2012): Characterization of the fungal microflora in raw milk and specialty cheeses of the province of Quebec, Dairy Sci Technol. 2012 Sep; 92(5): 455-468. 
Lodder, J. (1970): The yeasts A taxanomic study. $2^{\text {nd }}$ edition. North. Holland Publishing Company, Amesterdam.

Martins, M.; Martins, H.; Lowdes, M. and Lourdes, $H$. (1995): Occurrence of aflatoxin, ochratoxin, steromgasten and patulin in portuguess cheese, veterinariatechnia, 5(1):18.

Moawad, A.A.; Galal, E.A.; Abd El-Hady, H.M. and Dardir, H.A. (2002): Role of dairy plant in improving some aspects of kareish cheese. Egypt. Vet. Med., Ass., 62, (2): 157-165.

Moustafa, M.F. (2004): Studies on Escherichia coli O157: H7 in milk and some dairy products. Thesis, Ph.D, Fac. Vet. Med., Assiut Univ., Egypt.

Muir, D.D. and Banks, J.M. (2000): Milk and milk products in the stability and shelf life of food ed. D. Kilcastndp subramaniam,Woodhead publishing limited, Boca Raton. Fl.197-219.

Pardo, E.; Marín, S.; Solsona, A.; Sanchis, A. and Ramos, A. (2004): Modeling of germination and growth of ochratoxigenic isolates of Aspergillus ochraceus as affected by water activity and temperature on a barley-based medium. J. Food Microbiol., 21: 267-274.

Pešić-Mikulec, D.; Stojanović, L. and Jovanović, L. (2005): Moulds associated with milk depending on macroclimate and geographical location. App Ecol Environ Res 3(2): 61-65.

Ramirez, C. (1982): Manual and Atlas of the Penicillia. El-sevier Biomedical press. Amesterdam., New York., Oxford.

Robinson, R.K. and Tamime, A.Y. (1991): Manufactured of feta cheese industrial. In: Feta and related cheese. $1^{\text {st }}$ Ed. Ellis, H. ed Limited International Group, Academic Press, p:70136.

Samson, R.A. (1979): Complication for the asperigilli described since 1965. Studies in mycology No.18.

Sarais, I.; Piussi, D.; Aquili, V. and Stecchini, M.L. (1996): The behavior of yeast populations in stracchino cheese packaged under various conditions. J. Food Prot., 59, (5):541-544.

Scott, P.M and Trucksess, M.W. (1997): Application of immunoaffinity columns to mycotoxin analysis. J. AOAC Int. 80: 941-949.

Sengun, I.; Yaman, D. and Gonul, S. (2008): Mycotoxins and mould contamination in cheese World Mycotox. J., 3: 291-298.

Škrinjar, M.; Jakić-Dimić, D.; Blagojev, N. and Šošo, $V$. (2011): Results of one-year investigations of the contamination of dairy cattle feed and raw milk with moulds and mycotoxins. Biotechnol Anim Husb, 27(3): 985-992.

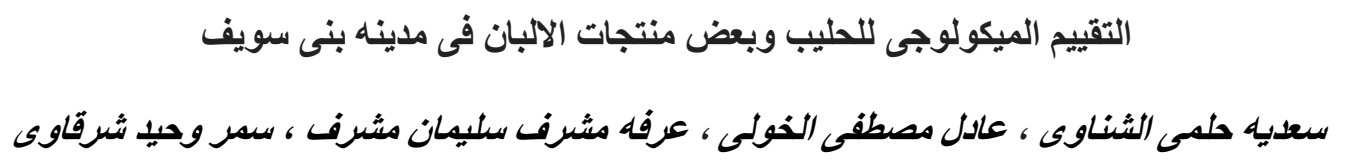

E-mail: ashrykhaled@gmail.com Assiut University web-site: www.aun.edu.eg

تم إخضاع ها (ا عينة من الحليب الخام ، الجبنة القريش المصنعة محليا ، الجبن الصلب (الجبنة الرومى) ، الزبادي العادي و الزبادى

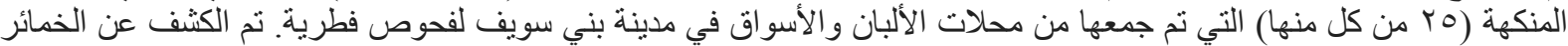

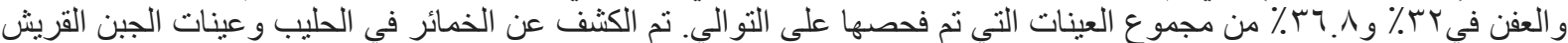

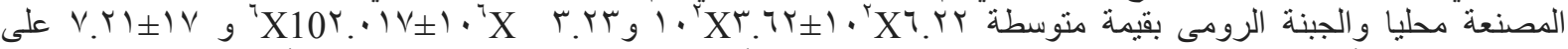

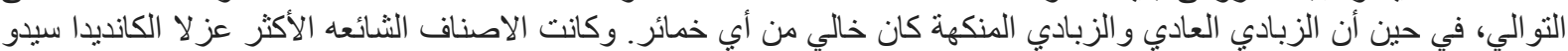

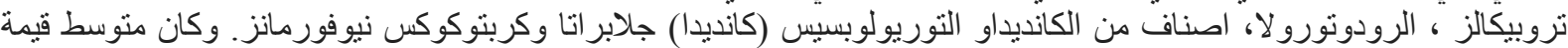

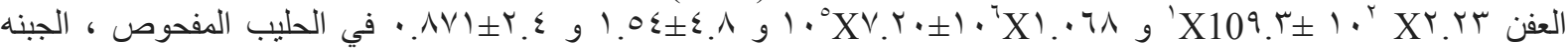

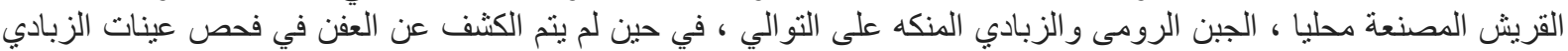

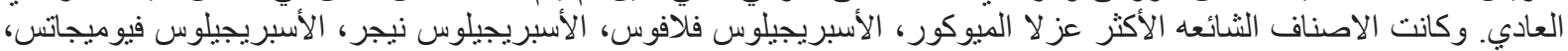

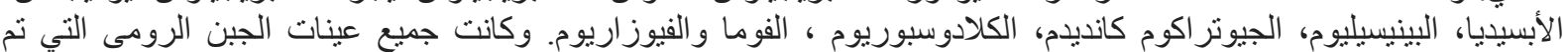

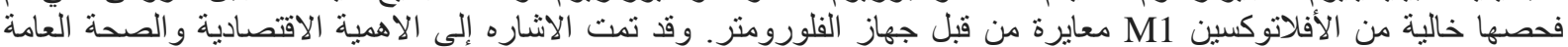
لوجود الفطريات و السموم الفطرية وكذلك الاحتين الاحتياطات الصحية. 